\title{
EVALUATION OF SIMPLIFIED ANTIPYRINE TEST IN CALVES
}

\author{
K. JANUS, J. SUSZYCKA, Z. MUSZCZYNSKI \\ Laboratory of Physiological Chemistry, Department of Animal Physiology, University of Agriculture, \\ Szczecin, Poland
}

Received July 26, 1996

Accepted March 20, 1997

\begin{abstract}
Janus, K., J. Suszycka, Z. Muszczynski: Evaluation of Simplified Antipyrine Test in Calves. Acta Vet. Brno 1997, 66:15-21.

The purpose of this study was to test a modification of antipyrine test in calves. The experiment was carried out on 10 calves (bulls of black and white breed). Each subject received on days 10 and 20 of life, respectively, $15 \mathrm{mg} . \mathrm{kg}^{-1}$ body mass of antipyrine as an intravenous bolus injection, followed by its oral administration "in substantia" in gelatin capsules 48 hours later. The concentrations of antipyrine in their saliva were repeatedly determined. Pharmacokinetics of antipyrine was followed in each subject (according to a one-compartment open model) using five modifications: a complete study (A), and four abbreviated studies, i.e using the 4,8 and $12 \mathrm{~h}$ saliva collection times (B), the 4 and $8 \mathrm{~h}$ collection times (C), further the 4 and $12 \mathrm{~h}(\mathrm{D})$, and finally the 8 and $12 \mathrm{~h}$ saliva collection times (E). Correlational analysis was used to compare the substance kinetics from the complete set of data obtained from all saliva collections with the results using each of the abbreviated approaches.

Based on the complete kinetics studies, mean variables for antipyrine were as follows: half-life $-12.00 \pm 1.12 \mathrm{~h}$, metabolic clearance $-0.75 \pm 0.06 \mathrm{ml} / \mathrm{min} / \mathrm{kg}$ (10-day-old calves) and $10.00 \pm 0.89 \mathrm{~h} ; 0.80 \pm 0.07 \mathrm{ml} / \mathrm{min} / \mathrm{kg}$ (20-day-old calves). Mean values determined by each of the four abbreviated methods were very similar, and values for abbreviated (B, C, D, E) vs. complete studies $(A)$ were highly significantly correlated: $t_{0.5}$ (10-day-old calves) : (B) vs (A) $r=0.985$, (C) vs (A) $-r=0.970$, (D) vs (A) $-r=0.962$, (E) vs $(A)-r=0.945 ; t_{0.5}$ (20 day-old calves), $r=0.980 ; 0.963 ; 0.971$ and 0.942 , respectively.

In conclusion, we demonstrated that antipyrine pharmacokinetic parameters in calves can be determined with reasonable precision using a two-point or three-point saliva sampling procedure following a single oral dose. Moreover, this simplified sampling method can be used for largescale investigations, where estimation of hepatic mixed function oxygenases (MFO) activity is needed.
\end{abstract}

Antipyrine, intravenous and oral administration, MFO system, calves

Antipyrine (Phenazone) has been widely used as a model substrate for cytochrome P-450 dependent metabolism (Danhof and Teunissen 1984; Poulsen and Loft 1988; Loft 1990). Antipyrine is eliminated primarily via hepatic metabolism, has a low intrinsic hepatic clearance, and is negligibly bound to tissue and plasma proteins (D an hof and B reimer 1989; Hartleb 1991; Konig and Cantilena 1994). Measurements of half-life and metabolic clearance of antipyrine have therefore been used to assess the drug-metabolizing activity of the liver in man and animals and its modification by genetic and multiple environmental factors (Danhof and Teunisen 1984; Depelchin et al. 1988; Loft 1990; Hartleb 1991).

Assessment of antipyrine pharmacokinetics can be made through measurement of its plasma or saliva concentrations (Harman et al. 1987; Loft et al. 1988; Sivagnanam et al. 1988; Vital-Durand et al. 1988; Loft et al. 1991). Discussions as to which of these biological fluids should be used have focused on the accuracy or convenience of each method (Scavone et al. 1988; Svensson 1988; Janus et al. 1991).

Estimation of pharmacokinetic parameters for antipyrine has traditionally required collection of up to ten or more blood samples during the 24 hours following administration 
of a single dose (Scavone et al. 1988; Hartleb 1991; Konig and Cantilena 1994). If antipyrine kinetics could be assessed with reasonable precision using less laborious blood sampling procedures, the usefulness of this test might be enhanced (Scavone et al. 1988; Sivaganam et al. 1988; Fabbri et al. 1991).

In domestic animals (especially in the neonatal period) relatively little is known about pharmacokinetics of antipyrine (Depel ch in et. al. 1988). Our previous experiment (J a nus et al. 1991) indicated that the measurement of antipyrine elimination rate from saliva after intravenous its administration can be used to assess the activity of hepatic monooxygenase system in calves.

The purpose of this study is further modification of the antipyrine test in calves. Based on antipyrine pharmacokinetic analysis after its intravenous and oral administration, we attempt to answer the following question: are the „noninvasive“ variants of the antipyrine test (oral administration of the drug, and determination of changes in salivary concentrations of antipyrine) suitable for a precise determination of the hepatic biotransformation rate (activity of mixed function oxygenases [MFO] system) in calves in their neonatal period? Therefore we also evaluated the suitability of several abbreviated methods for determination pharmacokinetics of antipyrine in calves.

\section{Materials and Methods}

\section{Animals}

The experiment was carried out on 10 calves (bulls of black and white breed). The animals were kept in single cages and fed in a common way. Before starting the experiment the calves were subjected to the catheterization vena jugularis externa. During the experiment the calves did not obtain any pharmacological substances that could interfere with antipyrine.

\section{Experimental procedures}

Each subject was given $15 \mathrm{mg} \cdot \mathrm{kg}^{-1}$ body mass of antipyrine (Phenazone - Sigma, USA.) on day 10 and 20 after birth as intravenous bolus injection (10\% aqueous sterile solution) followed 48 hours later by an i.v. administration of antipyrine ,,in substantia“" in a gelatin capsule. Saliva samples (about $5 \mathrm{ml}$ ) were collected as described previously (J a nu s et al. 1991), i.e. at ,0“, and 3, 4, 5, 6, 7, 8, 9, 10, 12, 18 and 24 hours after i.v. or oral drug administration. Samples were stored at $-20^{\circ} \mathrm{C}$ until analysed.

The concentration of antipyrine in saliva was determined by the spectrophotometric method according to Brodie et al. (1979).

The pharmacokinetics of antipyrine was calculated according to a one compartment open model, using results obtained in the slow phase $(\beta)$ of drug elimination (Loft 1990; Hartleb 1991). In these studies $\mathrm{k}_{\mathrm{el}}$ (elimination coefficient for antipyrine) and $\mathrm{C}_{\mathrm{o}}$ (initial concentration) were calculated by the least squares method from the curve of antipyrine concentration in plasma $(\mathrm{C})$ in relation to time $(\mathrm{t})$. Biological half-life of antipyrine $\left(\mathrm{t}_{0.5}\right)$ was calculated from the following relationship: $\mathrm{t}_{0.5}=0.693 / \mathrm{k}_{\mathrm{el}}$. Volume of antipyrine distribution $\left(\mathrm{V}_{\mathrm{d}}\right.$ ) was calculated from the following formula: $\mathrm{V}_{d}=\mathrm{D} / \mathrm{Co}$, when $\mathrm{D}=$ dose of antipyrine. Apparent volume of distribution (aV $\mathrm{V}_{d}$ ) was calculated as $\mathrm{aV}_{\mathrm{d}}=\mathrm{V}_{\mathrm{d}}$ /b.m., when b.m. = body mass. Antipyrine clearance $\left(\mathrm{Cl}_{\mathrm{A}}\right)$ was calculated as $\mathrm{Cl}_{\mathrm{A}}=\mathrm{aV} \mathrm{d}_{\mathrm{d}}{ }^{*} \mathrm{k}_{\mathrm{el}}$.

The bioavailability $(\mathrm{F})$ of antipyrine after oral administration was calculated according to the following formulas: $\mathrm{F}=\mathrm{AUC}_{\mathrm{or}} / \mathrm{AUC}_{\mathrm{i} . v \text {. }}$; in which $\mathrm{AUC}_{\text {or }}$ and $\mathrm{AUC}_{\mathrm{i} . \mathrm{y} .}$ are the areas under the saliva concentration versus time curves (calculated according to the log-linear trapezoidal rule) extrapolated to infinity following oral and intravenous administrations, respectively.

Pharmacokinetics of antipyrine for each subject were determined in the following five ways:
A) complete study, i.e. using all saliva samplings,
B) using the 4,8 and $12 \mathrm{~h}$ sampling points only
C) using the 4 and $8 \mathrm{~h}$ sampling points only
D) using the 4 and $12 \mathrm{~h}$ sampling points only
E) using the 8 and $12 \mathrm{~h}$ sampling points only.

Correlational analysis was used to compare kinetic results from the complete set of data (sampling times) with results using each of the abbreviated approaches.

Statistics

For statistical analysis the paired Student' t-test was used. Statistical and pharmacokinetics calculations were performed on an $486 \mathrm{DX} / 40$ computer system. 


\section{Results and Discussion}

The mean pharmacokinetic data for antipyrine obtained from measurements in saliva are presented in Tables 1 and 2 . Correlation coefficients between the complete and abbreviated studies for half-life and metabolic clearance of antipyrine are presented in Table 3. Based on the complete kinetics studies, mean kinetic variables for antipyrine were as follows: halflife $-12.0 \pm 01.12 \mathrm{~h}$, metabolic clearance $-0.75 \pm 0.06 \mathrm{ml} / \mathrm{min} / \mathrm{kg}$ (10-day-old calves) and $10.00 \pm 0.89 \mathrm{~h} ; 0.80 \pm 0.07 \mathrm{ml} / \mathrm{min} / \mathrm{kg}$ (20-day-old calves), see Tables 1 and 2 . Mean values determined by each of the four abbreviated studies were very similar, and values for abbreviated vs. complete studies were highly significantly correlated (Table 3 ).

Table 1

Pharmacokinetic parameters of antipyrine in saliva after intravenous and per os administration (10 day-old calves) $(n=10, \bar{x} \pm S D)$

\begin{tabular}{|c|c|c|c|}
\hline \multirow{2}{*}{$\begin{array}{l}\text { PHARMACOKINETIC } \\
\text { PARAMETERS }\end{array}$} & \multicolumn{2}{|c|}{$\begin{array}{c}\text { ROUTE OF } \\
\text { ADMINISTRATION }\end{array}$} & \multirow{2}{*}{$\begin{array}{c}\text { LEVEL OF } \\
\text { SIGNIFICANCE } \\
\text { I.V. vs. P.O. }\end{array}$} \\
\hline & I.V. & P.O. & \\
\hline $\mathrm{C}_{0}(\mu \mathrm{g} / \mathrm{ml})$ & $\begin{array}{r}32.10 \\
2.51\end{array}$ & $\begin{array}{r}32.75 \\
2.94\end{array}$ & $P>0.05$ \\
\hline $\mathrm{V}_{\mathrm{d}}(\mathrm{l})$ & $\begin{array}{r}31.15 \\
3.08\end{array}$ & $\begin{array}{r}30.53 \\
3.03\end{array}$ & $\mathrm{P}>0.05$ \\
\hline $\mathrm{aV}_{\mathrm{d}}(\mathrm{l} / \mathrm{kg})$ & $\begin{array}{l}0.78 \\
0.07\end{array}$ & $\begin{array}{l}0.76 \\
0.05\end{array}$ & $P>0.05$ \\
\hline$t_{0.5}(h)$ & $\begin{array}{r}12.00 \\
1.12\end{array}$ & $\begin{array}{r}11.70 \\
1.10\end{array}$ & $P>0.05$ \\
\hline$k\left(h^{-1}\right)$ & $\begin{array}{l}0.058 \\
0.004\end{array}$ & $\begin{array}{l}0.060 \\
0.004\end{array}$ & $\mathrm{P}>0.05$ \\
\hline $\mathrm{Cl}_{\mathrm{A}}(\mathrm{ml} / \mathrm{min})$ & $\begin{array}{r}30.09 \\
2.48\end{array}$ & $\begin{array}{r}30.31 \\
2.98\end{array}$ & $P>0.05$ \\
\hline $\mathrm{Cl}_{\mathrm{A}}(\mathrm{ml} / \mathrm{min} / \mathrm{kg})$ & $\begin{array}{l}0.75 \\
0.06\end{array}$ & $\begin{array}{l}0.77 \\
0.07\end{array}$ & $\mathrm{P}>0.05$ \\
\hline $\operatorname{AUC}\left(\mu \mathrm{g} * \mathrm{~h}^{*} \mathrm{ml}^{-1}\right)$ & $\begin{array}{r}554.00 \\
36.11\end{array}$ & $\begin{array}{r}550.11 \\
21.84\end{array}$ & $P>0.05$ \\
\hline $\mathrm{F}(1 / 1)$ & & & \\
\hline
\end{tabular}

Legend: $\mathrm{C}_{0}$ - initial concentration of antipyrine; $\mathrm{V}_{\mathrm{d}}$ - volume of distribution; $\mathrm{aV}_{\mathrm{d}}$ - apparent volume of distribution; $\mathrm{t}_{0.5}$ - half-life; $\mathrm{k}$ - elimination coefficient; $\mathrm{Cl}_{\mathrm{A}}$ - metabolic clearance; $\mathrm{AUC}$ - area under curve; $\mathrm{F}$ - bioavailability

Except for man, only few comparative data are available on the pharmacokinetics of antipyrine after intravenous and oral administration. In general, it is difficult to determine whether pharmacokinetics data obtained in calves can be extrapolated directly to man and laboratory animals (Depelchin et al. 1988; Janus et al. 1991).

The results obtained in the present study indicate that the pharmacokinetics of antipyrine in saliva of calves after intravenous and oral administration are very similar. This observation is in agreement with data presented by Eichelbaum et al. (1982). Likewise, Danhof et al. (1982) reported very similar values of metabolic clearance of antipyrine in man after intravenous and oral administration. They proved good correlation between the $\mathrm{Vd}, \mathrm{t} 0.5$ and $\mathrm{ClA}$ values that were independent of the route of antipyrine administration and 
Table 2

Pharmacokinetic parameters of antipyrine in saliva after intravenous and per os administration ( 20 day-old calves) $(n=10, \bar{x} \pm S D)$

\begin{tabular}{|c|c|c|c|}
\hline \multirow{2}{*}{$\begin{array}{l}\text { PHARMACOKINETIC } \\
\text { PARAMETERS }\end{array}$} & \multicolumn{2}{|c|}{$\begin{array}{c}\text { ROUTE OF } \\
\text { ADMINISTRATION }\end{array}$} & \multirow{2}{*}{$\begin{array}{c}\begin{array}{c}\text { LEVEL OF } \\
\text { SIGNIFICANCE }\end{array} \\
\text { I.V. vs. P.O. }\end{array}$} \\
\hline & I.V. & P.O. & \\
\hline $\mathrm{C}_{0}(\mu \mathrm{g} / \mathrm{ml})$ & $\begin{array}{r}28.01 \\
3.03\end{array}$ & $\begin{array}{r}28.57 \\
2.94\end{array}$ & $\mathrm{P}>0.05$ \\
\hline $\mathrm{V}_{\mathrm{d}}(\mathrm{l})$ & $\begin{array}{r}35.70 \\
2.94\end{array}$ & $\begin{array}{r}35.09 \\
3.03\end{array}$ & $\mathrm{P}>0.05$ \\
\hline $\mathrm{aV}_{\mathrm{d}}(1 / \mathrm{kg})$ & $\begin{array}{l}0.70 \\
0.06\end{array}$ & $\begin{array}{l}0.69 \\
0.05\end{array}$ & $P>0.05$ \\
\hline $\mathrm{t}_{0.5}(\mathrm{~h})$ & $\begin{array}{r}10.00 \\
0.89\end{array}$ & $\begin{array}{l}9.67 \\
0.80\end{array}$ & $\mathrm{P}>0.05$ \\
\hline $\mathrm{k}\left(\mathrm{h}^{-1}\right)$ & $\begin{array}{l}0.069 \\
0.005\end{array}$ & $\begin{array}{l}0.072 \\
0.006\end{array}$ & $P>0.05$ \\
\hline $\mathrm{Cl}_{\mathrm{A}}(\mathrm{ml} / \mathrm{min})$ & $\begin{array}{r}41.04 \\
3.37\end{array}$ & $\begin{array}{r}41.98 \\
4.15\end{array}$ & $P>0.05$ \\
\hline $\mathrm{Cl}_{\mathrm{A}}(\mathrm{ml} / \mathrm{min} / \mathrm{kg})$ & $\begin{array}{l}0.80 \\
0.07\end{array}$ & $\begin{array}{l}0.83 \\
0.08\end{array}$ & $P>0.05$ \\
\hline $\operatorname{AUC}\left(\mu \mathrm{g}^{*} \mathrm{~h}^{*} \mathrm{ml}^{-1}\right)$ & $\begin{array}{r}406.18 \\
27.11\end{array}$ & $\begin{array}{r}396.86 \\
30.05\end{array}$ & $P>0.05$ \\
\hline$F(1 / 1)$ & & & \\
\hline
\end{tabular}

Table 3

Correlation coefficients between complete study and abbreviated studies for half-life $\left(t_{0.5}\right)$ and metabolic clearance $\left(\mathrm{Cl}_{A}\right)$ of antipyrine

\begin{tabular}{|l|c|c|c|c|}
\hline \multirow{2}{*}{$\begin{array}{l}\text { VARIANTS } \\
\text { OF ANTIPYRINE TEST }\end{array}$} & \multicolumn{4}{|c|}{ AGE OF CALVES } \\
\cline { 2 - 5 } & $\mathrm{t}_{0.5}(\mathrm{~h})$ & $\mathrm{Cl}_{\mathrm{A}}(\mathrm{ml} / \mathrm{min})$ & $t_{0.5}(\mathrm{~h})$ & $\mathrm{Cl}_{\mathrm{A}}(\mathrm{ml} / \mathrm{min})$ \\
\cline { 2 - 5 } & 1.000 & 1.000 & 1.000 & 1.000 \\
COMPLETE STUDY & & & & \\
ABBREVIATED STUDIES & $0.985^{* *}$ & $0.977^{* *}$ & $0.980^{* *}$ & $0.969^{* *}$ \\
4,8 and 12 h points & $0.970^{* *}$ & $0.972^{* *}$ & $0.963^{* *}$ & $0.960^{* *}$ \\
4 and 8 h points & $0.962^{* *}$ & $0.955^{* *}$ & $0.971^{* *}$ & $0.963^{* *}$ \\
4 and 12 h points & $0.945^{* *}$ & $0.942^{* *}$ & $0.942^{* *}$ & $0.939^{* *}$ \\
\hline 8 and 12 h points & & & & \\
\hline
\end{tabular}

Notices: ${ }^{* *}$ - correlation coefficient significantly at $\mathrm{P}<0.01$ level

the biological fluid (plasma, saliva) in which the concentration of the drug was determined. The authors found that independently of the route of antipyrine administration, about $65 \%$ of the drug dose was excreted in urine as its metabolites. In both cases only $4 \%$ administered dose was excreted in urine as unchanged antipyrine.

Andreasen and Vesell (1974) reported that in man antipyrine is almost completely absorbed from the gastrointestinal tract (bioavailability: $F \gg 1$ ) and did not exhibit 
a detectable „first-pass“ phenomenon; therefore it is possibly a precise determination of $\mathrm{V}_{\mathrm{d}}$ and $\mathrm{Cl}_{\mathrm{A}}$ values after oral administration.

Bioavailability of antipyrine in calves after its administration in gelatin capsules amounted to $0.96 \pm 0.03$ in 10-day-old, and $0.97 \pm 0.04$ in 20-day-old calves. Similar results were found in man by Eichelbaum et al. (1982), Paradowski (1987) and Danhof et al. (1982). The latter authors administered antipyrine orally as an aqueous solution and in gelatin capsules, and demonstrated that an aqueous solution of antipyrine is fully bioavailable $(F=1.05 \pm 0.11)$, whereas when given as capsules its absorption from the gastrointestinal tract was not always complete $(\mathrm{F}<0.9)$. A different opinion is presented by Welch et al. (1975). They demonstrated that when antipyrine was given in gelatin capsules, its bioavailability was practically always very high. They also found that when antipyrine was administered orally as an aqueous solution, its salivary concentration did not reflect the plasma concentration until $1 \mathrm{~h}$ after administration. S vens s on (1988) and Vital-Durand et al. (1988) stated, in consequence of ,antipyrine retention" in the buccal mucosa after administration of its aqueous solution, that the drug administration in gelatin capsule allowed for ,more objective" separation of the absorption phase from the elimination phase. Vital-Durand et al. (1988) proved that the absorption phase of antipyrine (administered in gelatin capsule) from the gastrointestinal tract in adult man to amount about 120 min. Similar values were observed by Welch et al. (1975). They stated that the „true“ elimination phase of antipyrine from saliva (after oral administration) begins 120 min after the drug ingestion. In our previous experiment, the time of antipyrine absorption from the gastrointestinal tract of the examined calves was longer ( $\bar{x} t_{\max }=150 \mathrm{~min}$ ). The differences observed may be due to species differences or due to the fact that antipyrine in young calves was absorbed more slowly than in older or adult animals.

Attempts to establish the efficacy of simplified methods for determination of the pharmacokinetics of antipyrine have been previously reported in man. Dossing et al. (1982) calculated the antipyrine clearance based on a single sample only. This method, however, requires that the volume of distribution be either simply assumed or calculated from equations relating total body water to age, body mass or gender (Pilsgaard and Poulsen 1984). Danh of et al. (1982) stated that the one-sample test is especially applicable in investigations in which each subject serves as his own control and where no alterations in volume of distribution are expected. On the other hand, the test cannot be used in studies in which a measurement of $V_{d}$ from the antipyrine data is needed (Dossing et al. 1982).

Determination of the antipyrine clearance by the two or three-point saliva collection procedure in calves is reliable and simpler than multiple sampling. The optimal time interval from antipyrine administration to saliva sampling for its concentration measurement in the abbreviated studies was 4,8 and 12 hours. This observation is in agreement with data presented by Scavone et al. (1988) in man. Also Farrell and Zaluzny (1984) found good correlation in antipyrine clearance values between two-point and six-point studies.

In conclusion, we demonstrated a good agreement of antipyrine pharmacokinetic parameters calculated on the basis of changes in its saliva concentration after intravenous and oral administration. Furthermore, almost a $100 \%$ bioavailability of antipyrine in the examined animals shows that it is possible to evaluate precisely the hepatic biotransformation rate in healthy calves in the neonatal period using a noninvasive modification of the antipyrine test. The test consists of antipyrine administration in a gelatin capsule and later determination of changes in its saliva concentration. We have also demonstrated that antipyrine pharmacokinetic parameters can be measured with reasonable precision using a simplified two-point or three-point saliva sampling procedure following a single oral dose. 


\section{Vyhodnocení jednoduchého antipyrinového testu u telat}

Cílem studie bylo ověřit modifikaci antipyrinového testu u telat. Pokus byl proveden na 10 telatech (býčci černobílého plemene). Každému jedinci byl 10. a 20. dne po narození podán iv. antipyrin $\mathrm{v}$ dávce $15 \mathrm{mg} \cdot \mathrm{kg}^{-1}$ živé hmotnosti. Za $48 \mathrm{~h}$ jim byl antipyrin podán $\mathrm{v}$ želatinových kapslích. Poté byla měřena koncentrace antipyrinu ve slinách telat. Jeho farmakodynamika byla sledována za použití 5 schemat odběru vzorkủ slin: kompletní studie (A), za použití vzorkủ odebraných po 4,8 a 12 h (B), dále po 4 a 8 h (C), po 4 a 12 h (D), a konečně po 8 a $12 \mathrm{~h}($ E). Korelační analýza byla použita $\mathrm{k}$ porovnání výsledkủ kinetiky z kompletních údajủ a ze zkrácených studií B-E.

Na základě kompletní kinetické studie byly zjištěny následující parametry pro antipyrin: poločas $12.00 \pm 1.12 \mathrm{~h}$, metabolická clearance $0.75 \pm 0.06 \mathrm{ml}$ min. $\mathrm{kg}$ (10 d stará telata) a $10.00 \pm 0.89 \mathrm{~h}, 0.80 \pm 0.07 \mathrm{ml} . \mathrm{min} . \mathrm{kg}(20 \mathrm{~d}$ stará telata). Průměrné hodnoty stanovené každou ze čtyř zkrácených metod byly velmi podobné, a jejich hodnoty $(\mathrm{B}, \mathrm{C}, \mathrm{D}, \mathrm{E})$ byly vysoce a signifikantně korelovány s kompletní metodou $(\mathrm{A}): \mathrm{t}_{0.5}$ (10denní telata):(B) versus (A) $\mathrm{r}=0.985,(\mathrm{C})$ versus $(\mathrm{A}) \mathrm{r}=0.970,(\mathrm{D})$ versus $(\mathrm{A}) \mathrm{r}=0.962,(\mathrm{E})$ versus $(\mathrm{A})$ $\mathrm{r}=0.945$; hodnoty $\mathrm{t}_{0.5}(20 \mathrm{~d}$ stará telata $)$, byly $\mathrm{r}=0.980,0.963,0.971,0.942$.

V této studii jsme prokázali, že farmakiokinetické parametry antipyrinu u telat lze stanovit $s$ dostatečnou přesností za použití zjednodušené metody a dvou nebo tř́ odběrů slin po jediné orální aplikaci látky. Metoda je vhodná i pro použití ve velkém měřítku, např. při vyక̌etřování funkce jaterní monooxidázové aktivity (MFO).

\section{Acknowledgments}

This work was supported by grant No. BW/D/Z/55/95 at the University of Agriculture, Szczecin, Poland.

\section{References}

ANDREASEN, P. B, VESELL, E. S. 1974: Comparison of plasma levels of antipyrine, tolbutamide and warfarin after oral and intravenous administration. Clin. Pharmacol. Ther. 16:1059-1065

BRODIE, B. B., AXELROD, J., SOBERMAN, R., LEVY, B.1979: The estimation of antipyrine in biological materials. J. Biol.Chem. 179:25-29

DANHOF, M., ZLILEN, A., BOEIJINGA, J. K., BREIMER, D. D. 1982: Studies on the different metabolic pathways of antipyrine in man: oral versus i.v. administration and the influence of urinary collection time. Eur. J. Clin. Pharmacol. 21:433-441

DANHOF, M., TEUNISSEN, M. W. 1984: Antipyrine as a model drug to assess oxidative drug metabolizing in man. Pharm. Int. 5:11-15

DANHOF, M, BREIMER, D. D. 1989: Study on the different metabolic pathways of antipyrine in man. I. Oral administration of 250,500 and $1000 \mathrm{mg}$ to healthy volunteers. Br. J. Clin. Pharmacol. 8:529-537

DEPELCHIN, B. O., BLODEN, S., MICHAUX, C., ANSAY, M. 1988:Effect of age, sex and breed on antipyrine disposition in calves. Res. Vet. Sci. 44:135-139

DOSSING, M., POULSEN, H. E., ANDREASEN, P. B., TYGSTRUP, N. 1982: A simple method for determination of antipyrine clearance. Clin. Pharmacol. Ther. 32:392-396

EICHELBAUM, M., OCHS, H. R., ROBERTS, G., SOMOGYI, A. 1982: Pharmacokinetics and metabolism of antipyrine after intravenous and oral administration. Arzneimitt. Forsch. 32:575-578

FABBRI, A., BIANCHI, G., ZOLI, M., MARCHI, E., MERCHESINI, G. 1991: Effect of physical exercise on onesample antipyrine clearance. Ital. J. Gastroent. 23:74-76

FARRELL, G. C., ZALUZNY, L. 1984: Accuracy and clinical utility of simplified test of antipyrine metabolism. Br. J. Clin. Pharmacol. 18:559-565

HARMAN, A. W., PRIESTLY, B. G., FREWIN, D. B. 1987: A comparative study of antipyrine pharmacokinetics in saliva and plasma using a colorimetric method of antipyrine analysis. Clin. Exp. Pharmacol. Physiol. 4:593-596

HARTLEB, M. 1991:Drug and the liver. Part. II. The role of antipyrine test in drug metabolism studies. Biopharm. Drug Disp. 12:559-571

JANUS, K., BARANOW-BARANOWSKI, S., JAKUBOWSKA, D. 1991:Trials to assessment of hepatic biotransformation rate in calves on the basis of the rate of antipyrine elimination from saliva. Arch. Vet. Pol. 31:65-71 
KONIG, P. K., CANTILENA, L. 1994: Antipyrine as a model drug substance to assess oxidative metabolism. Arch.Int. Med. 154:590-591

LOFT, S., POULSEN, H. E., SONNE, J., DOSSING, M. 1988: Metronidazole clearance -A one sample method and influencing factors. Clin. Pharmacol. Ther. 43:420-428

LOFT, S. 1990:Metronidazole and antipyrine as probes for the study of foreign compound metabolism, Pharmacol. Toxicol.(suppl. 6), 66:1-31

LOFT, S., NIELSEN, A. J., BORG, B. E., POULSEN, H. E. 1991:Metronidazole and antipyrine metabolism in the rat: clearance determination from one saliva sample. Xenobiotica 21:33-46

PARADOWSKI, L. 1987: The effect of somatostatin on bioavailability of antipyrine in healthy man. Pol. Tyg. Lek. 42:1192-1194

PILSGAARD, H., POULSEN, H. E. 1984:A one-sample method for antipyrine clearance determination in rats. Pharmacology 29:110-118

POULSEN, H. E., LOFT, S. 1988: Antipyrine as a model drug to study hepatic drug-metabolizing capacity. J. Hepatol. 6:374-378

SCAVONE, J. M., GREENBLATT, D. J., BLYDEN, G. T., HARMATZ, J. S. 1988: Simplified approach to the determination of antipyrine pharmacokinetic parameters. Br. J. Clin. Pharmacol. 25:695-699

SIVAGNANAM, G., ADITHAN, C., RAVEENDRAN, R., SHASHINDRAN, C. H., BAPNA, J. S. 1988: Evaluation of simplified antipyrine test in plasma. Ind. J. Med. Res. 87:80-83

SVENNSON, C. K. 1988: Is blood sampling for determination of antipyrine pharmacokinetics in healthy volunteers ethically justified? Clin. Pharmacol. Ther. 44:365-369

VITAL-DURAND, D., PIOLAT, C., SOUCHELEAU, J., BALTASSAT, P., BRAZIER, J. L.1988: Pharmacocinetique de l'antipyrine. Comparaison les concentrations totales, libres et salivaires. Therapie 43:263-266

WELCH, R. M., DE ANGELIS, R. L., WINGFIELD, M., FARMER, T. W. 1975: Elimination of antipyrine from saliva as a measure of metabolism in man. Clin. Pharmacol. Ther. 18:249-25

Address for correspondence:

Prof. Dr. K. Janus

Laboratory of Physiological Chemistry

Department of Physiology

University of Agriculture

ul. Doktora Judyma 6

71-466 Szczecin

Poland 